\title{
Signos en Neurorradiología
}

\author{
Federico Roca ${ }^{1}$ \\ ${ }^{1}$ Neuroradiología diagnóstica y terapéutica, Secretario General de \\ SORDIC, miembro de FAARDIT, miembro del Colegio Argentino de \\ Neurointervencionismo (CANI)
}

Rev Argent Radiol 2020;84:136.

\section{Pablo Sartori. Signos en Neurorradiología. Buenos Aires: Ediciones Journal}

El libro Signos en Neuroradiología aparece como una importante y necesaria herramienta diagnóstica para el escritorio del neuroradiólogo.

Su autor, Pablo Sartori, con reconocidos y destacados colaboradores, realiza una detallada descripción de los principales signos radiológicos de diversas patologías neurológicas. Con una finalidad didáctica e ilustrativa, el libro reúne cerca de un centenar de signos, ordenados en categorías según la patología y con una excelente correlación con imágenes de tomografia computada o resonancia magnética.

Cada capítulo está dedicado a una patología o región anatómica específica, a los que se suma un capítulo de signos varios. Estos desarrollan una exhaustiva descripción de los signos radiológicos principales, de fácil lectura e interpretación, con sus correspondientes diagnósticos diferenciales, facilitando la fijación de conocimientos con su correlato imagenológico.

Su lectura resultará de gran interés, ideal para residentes en formación o para refrescar conocimientos a los especialistas.

La mayor parte de los signos radiológicos descriptos se evidencian en resonancia magnética nuclear, solo 13 exclusivamente en tomografía computada y algunos pocos en angiografía digital ("bocanada de humo") o radiografía (“cráneo de algodón").

La gran variedad de signos radiológicos incluidos permite al lector asociar la imagen con la patología específica, lo que favorece el aprendizaje y la fijación del contenido.

Se describen numerosos signos relacionados con objetos de la vida diaria (satélite, cuerda, tridente), otros relativos a animales (ojos, cabeza, garra), geográficos (monte Fuji) o del alfabeto griego (tau, delta).
Address for correspondence Federico Roca, Neuroradiología diagnóstica y terapéutica, Secretario General de SORDIC, miembro de FAARDIT, miembro del Colegio Argentino de Neurointervencionismo (CANI), (e-mail: federoca@gmail.com).

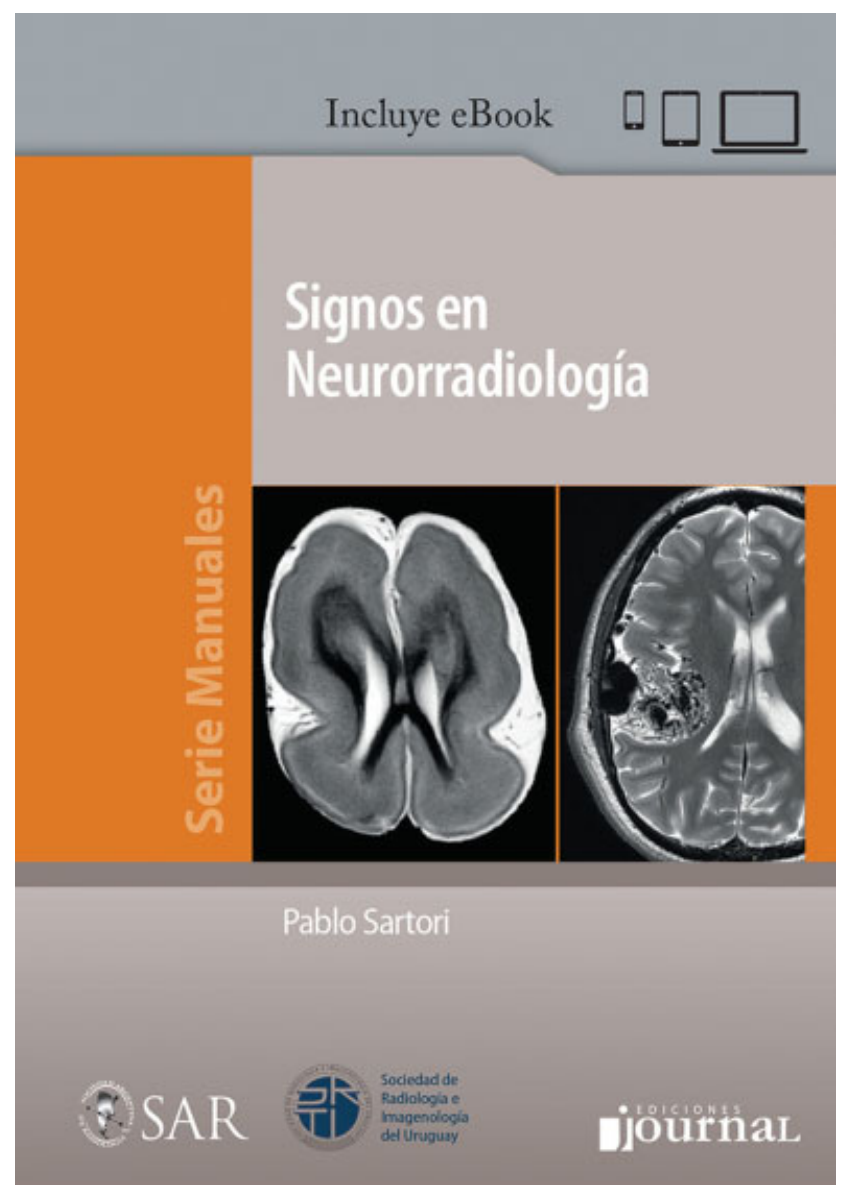

Más de 100 imágenes separadas por categorías complementan y dan color a la descripción de estos intrigantes signos neuroradiológicos.

(c) 2020. Sociedad Argentina de Radiología. All rights reserved. This is an open access article published by Thieme under the terms of the Creative Commons Attribution-NonDerivative-NonCommercial-License, permitting copying and reproduction so long as the original work is given appropriate credit. Contents may not be used for commercial purposes, or adapted, remixed, transformed or built upon. (https://creativecommons.org/ licenses/by-nc-nd/4.0/)

Thieme Revinter Publicações Ltda., Rua do Matoso 170, Rio de Janeiro, RJ, CEP 20270-135, Brazil 